\title{
CDC45 wt Allele
}

National Cancer Institute

\section{Source}

National Cancer Institute. CDC45 wt Allele. NCI Thesaurus. Code C52287.

Human CDC45 wild-type allele is located in the vicinity of 22 q11.21 and is approximately $41 \mathrm{~kb}$ in length. This allele, which encodes cell division control protein 45 homolog, plays a role in the progression of the cell cycle. The gene is required for the regulation of chromosomal replication. Mutation of the gene is associated with Meier-Gorlin syndrome 7. 